\title{
Pengembangan Startup Guna Meningkatkan Penjualan Beras Organik di Kabupaten Banyuwangi Memanfaatkan Metode Design Sprint
}

\author{
Eko Heri Susanto ${ }^{1}$, Hadiq ${ }^{2}$ \\ Program Studi Teknik Informatika STIKOM PGRI Banyuwangi ${ }^{1,2}$ \\ ekoheri@gmail.com ${ }^{1}$, hadiqfawzie@gmail.com²
}

\begin{abstract}
Banyuwangi Regency, East Java province, is one of the organic rice producers which manage to export its products abroad. PT. Sirtanio Indonesia is one of the companies that produce organic rice in Banyuwangi. The problems faced by PT. Sirtanio Indonesia which is a partner of community service activities is how to increase sales of organic rice in Indonesia, especially in Banyuwangi. For this reason, community service activities are aimed at developing startup companies to help partners to increase sales of organic rice. In order to optimize the process of mapping problems and solutions presented by the startup, the Google design sprint method is used in this activity. The Google design sprint method only takes approximately 1 (one) year to ensure the business process of the startup company can run well. The media for promotion and sale of organic rice can be accessed through the website https://organiku.id. From this series of activities, it can be proven that the sale of organic rice is increased. It is recorded from April 2018 to January 2019, there have been sales transactions of 257 Kilograms. In an effort to legalize the business process of this pilot company, a business entity has been established in the form of a partnership company called CV. Pipo Organiku, with notarial deed number 36, September 24, 2018.
\end{abstract}

Keywords: Sale of Organic Rice; Startup; Design Sprint.

\begin{abstract}
Abstrak
Kabupaten Banyuwangi provinsi Jawa Timur, merupakan salah produsen beras organik yang berhasil mengekspor produknya ke luar negeri. PT. Sirtanio Indonesia adalah salah satu perusahaan yang memproduksi beras organik di Banyuwangi. Salah satu permasalahan PT. Sirtanio Indonesia yang menjadi mitra dari kegiatan ini adalah bagaimana meningkatkan penjualan beras organik di Indonesia khususnya di Banyuwangi. Kegiatan ini ditujukan untuk mengembangkan perusahaan rintisan atau startup guna membantu mitra untuk meningkatlan penjualan beras organik tersebut. Guna mengoptimalkan proses pemetaan masalah dan solusi yang dihadirkan oleh startup tersebut, dalam kegiatan ini dimanfaatkan metode google design sprint. Dengan pemanfaatan metode google design sprint ini, terbukti hanya perlu waktu kurang lebih 1 (satu) tahun, untuk memastikan proses bisnis perusahaan rintisan bisa berjalan dengan baik. Adapun media untuk promosi dan penjualan beras organik, dapat diakses melalui website https://organiku.id. Dari serangkaian kegiatan ini, dapat dibuktikan bahwa penjualan beras organik meningkat. Tercatat dari bulan April 2018 sampai dengan Januari 2019, sudah ada transaksi penjualan sebanyak 257 Kilogram (Kg). Sebagai upaya untuk melegalkan proses bisnis perusahaan rintisan ini, maka telah berhasil didirikan badan usaha yang berbentuk perseroan komanditer yang bernama CV. Pipo Organiku, dengan akta notaris nomor 36, tanggal 24 September 2018.
\end{abstract}

Kata Kunci: Penjualan Beras Organik; Startup; Design Sprint. 


\section{A. PENDAHULUAN}

Padi adalah komoditas yang penting di Indonesia, karena beras yang dihasilkan dari padi merupakan makanan pokok untuk masyarakat Indonesia (U. Nations, 2009). Kabupaten Banyuwangi Provinsi Jawa Timur adalah salah satu kabupaten di Indonesia yang mampu memproduksi beras organik dengan jumlah yang paling stabil di Indonesia. Bahkan beras organik Banyuwangi, sudah berhasil diekspor ke beberapa Negara antara lain Belanda dan Amerika Serikat (banyuwangikab.go.id, 2016).

Salah satu perusahaan penghasil beras organik di Kabupaten Banyuwangi adalah PT. Sirtanio Indonesia, dimana PT. Sirtanio ini sudah mengantongi sertifikat organik. Sampai saat ini, PT. Sirtanio Indonesia yang beralamatkan di desa Sumberbaru, kecamatan Singojuruh, Kabupaten Banyuwangi, sudah mengelola lahan organik seluas kurang lebih 80 hektar (banyuwangikab.go.id, 2016). Untuk selanjutnya, PT. Sirtanio Indonesia ini dijadikan mitra oleh STIKOM PGRI Banyuwangi, dimana salah satu tujuan program kemitraan tersebut adalah bagaimana meningkatkan penjualan produk beras organik di Indonesia pada umumnya dan di kabupaten Banyuwangi khususnya.

Keberhasilan Banyuwangi dalam mengekspor produk beras organik merupakan kebanggaan tersendiri bagi petani maupun pemerintah daerah. Namun, alangkah dilematisnya, manakala justru penjualan beras organik di dalam negeri khususnya di Banyuwangi malah sangat minim. Hal ini sesuai dengan pengakuan dari mitra yaitu PT. Sirtanio, yang menyatakan bahwa penjualan beras organik di dalam negeri malah tidak sebanyak penjualan beras ke luar negeri.

Untuk membuktikan pernyataan ini, STIKOM PGRI Banyuwangi telah membentuk tim kecil untuk melakukan survey ke masyarakat khususnya ibu-ibu rumah tangga. Tim kecil ini direkrut dari mahasiswamahasiswa STIKOM PGRI Banyuwangi. Dari hasil survey yang dilakukan oleh tim mahasiswa itu tadi, didapatkan data sementara bahwa beberapa ibu-ibu rumah tangga di Kabupaten Banyuwangi, justru tidak mengetahui keberadaan beras organik di Kabupaten Banyuwangi. Padahal beras organik menurut hasil uji laboratorium menunjukkan tidak ada residu racun yang terkandung dalam berasnya, dan tentu saja beras organik merupakan bahan makanan yang sehat untuk dikonsumsi.

Jauh-jauh hari sebelum kegiatan ini dilaksanakan, penulis sudah mempunyai hipotesa bahwa penjualan beras organik merupakan salah satu masalah utama yang dihadapi oleh petani pada umumnya dan khususnya mitra yaitu PT. Sirtanio Indonesia. Penulis berasumsi bahwa penjualan beras ini membutuhkan penanganan yang khusus dan harus fokus. Oleh karena itu, penulis mencoba membuat inovasi yang khusus menangani penjualan beras organik ini, melalui perusahaan rintisan atau diistilahkan startup. Dikarenakan latar belakang keilmuan penulis adalah bidang teknik informatika, maka startup penjualan beras organik ini diwujudkan dalam bentuk pemasaran online atau online marketing.

Dalam pengambangan startup, tentu tidak bisa gegabah dalam merumuskan permasalahan dan solusi apa yang akan dihadirkan, khususnya solusi penjualan beras organik di Kabupaten Banyuwangi. Untuk mengefisienkan pengembangan model startup yang ingin dikembangkan, maka dalam kegiatan ini penulis menggunakan metode google design sprint atau yang dikenal dengan metode design sprint. Metode design sprint sudah terbukti mampu menghasilkan atau 
memetakan permasalahan dan solusi secara tepat dan cepat (Knapp, 2017).

Adapun tujuan dari pemanfaatan design sprint ini, diharapkan bisa menghadirkan solusi yang tepat sasaran terhadap masalah yang dihadapi petani padi khususnya adalah masalah penjualan beras organik. Selain itu, dari pengembangan startup ini, diharapkan mampu menghadirkan perusahaan rintisan yang mana perusahaan rintisan ini diupayakan mempunyai badan hukum, sehingga secara legal formal perusahaan rintisan ini mempunyai kekuatan hukum dalam menjalankan transaksi bisnisnya. Dengan keberadaan perusahaan rintisan yang berbadan hukum ini, harapannya kampus STIKOM PGRI Banyuwangi mampu berinovasi, dimana inovasi ini adalah sebagai bukti nyata bahwa kampus STIKOM PGRI Banyuwangi mempunyai andil sebagai kampus yang mampu berperan sebagai agen pembangun ekonomi (agent of economic development), seperti yang sudah dicanangkan oleh Kementerian Riset, Teknologi dan Pendidikan Tinggi atau Kemenristekdikti (Permenristekdikti, 2015).

\section{B. PELAKSAAAN DAN METODE}

\section{Pelaksanaan Kegiatan}

Kegiatan pengabdian kepada masyarakat ini dilaksanakan sejak bulan oktober 2017 sampai dengan bulan Januari 2019. Dalam pelaksanaan program pengabdian kepada masyarakat ini, penulis membuat skenario untuk bekerjasama atau kolaborasi dengan 3 (tiga) elemen, yaitu yang pertama adalah tim mahasiswa, yang kedua adalah tim mentor yang terdiri dari dosen dan praktisi (expert) dan elemen yang ketiga adalah mitra yaitu PT. Sirtanio Indonesia. Skema kolaborasi ketiga elemen tersebut terlihat seperti pada Gambar 1.

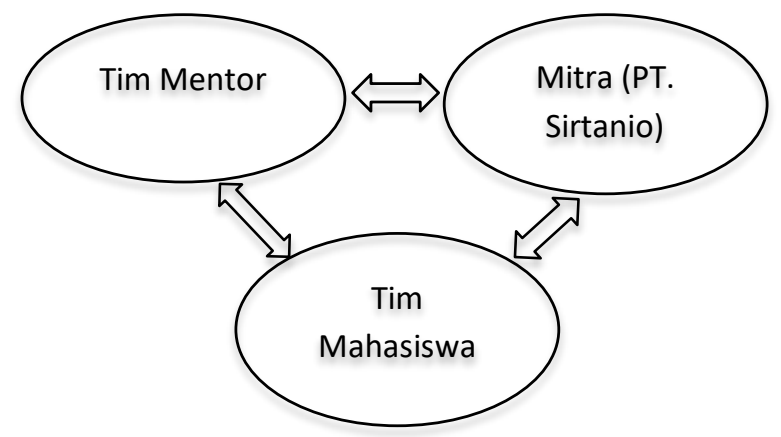

Gambar 1. Skema Kolaborasi Tim

Tim mentor tediri dari 6 orang yang berprofesi sebagai dosen dan pengusaha (praktisi). Tugas utama dari tim mentor ini adalah mengarahkan kepada mahasiswa mengenai hal-hal yang harus dikerjakan oleh tim mahasiswa. Adapun beberapa kegiatan yang diarahkan yaitu : menentukan jenis-jenis pekerjaan, mengevaluasi target pekerjaan dan membantu berkoordinasi dengan mitra. Adapun keenam tim mentor tersebut tertera seperti pada Tabel 1 berikut ini.

Tabel 1. Daftar Tim Mentor

\begin{tabular}{ccc}
\hline No & Nama & Pekerjaan \\
\hline 1 & Hadiq, ST., M.Kom & Dosen \\
\hline 2 & Eko Heri S., M.Kom & Dosen \\
\hline 3 & Putu Indra & Wiraswasta \\
\hline 4 & Rahmat Ramadhan I. & Wiraswasta \\
\hline 5 & Ahmad Faizal Rizal & Wiraswasta \\
\hline 6 & Junaidi Abdullah & Wiraswasta \\
\hline
\end{tabular}

Sedangkan tim mahasiswa adalah mahasiswa aktif STIKOM PGRI Banyuwangi, yang terdiri dari 8 orang. Adapun daftar tim mahasiswa tersebut tertera pada Tabel 2 berikut ini. Tugas utama dari tim mahasiswa ini adalah sebagai eksekutor kegiatan bisnis perusahaan rintisan yang fokusnya adalah dibidang promosi dan penjualan beras organik Banyuwangi. 
Tabel 2. Daftar Tim Mahasiswa

\begin{tabular}{ccc}
\hline No & Nama & Angkatan \\
\hline 1 & Nadiah Kartikawati & S1/2017 \\
\hline 2 & Rexsi Yudi Putra & S1/2017 \\
\hline 3 & B. Ario Catur W. & S1/2017 \\
\hline 4 & Bunga Hanum GAS & S1/2017 \\
\hline 5 & Syafrina Farahdila & S1/2017 \\
\hline 6 & Ovie Olyvia & $\mathrm{D} 3 / 2016$ \\
\hline 7 & Siti Masula & $\mathrm{D} 3 / 2016$ \\
\hline 8 & Nida Khoiruroh & $\mathrm{S} 1 / 2015$ \\
\hline
\end{tabular}

Sedangkan mitra dari kegiatan pengabdian masyarakat ini adalah PT.Sirtanio Indonesia, yang beralamatkan di desa Sumberbaru, kecamatan Singojuruh, kabupaten Banyuwangi Jawa Timur. Adapun tugas utama mitra adalah menyediakan stok beras organik, dengan berbagai macam jenis beras yang antara lain beras putih, beras merah dan beras hitam.

\section{Metode}

Metode yang digunakan pada program pengabdian ini adalah google design sprint. Secara garis besar, metode google design sprint atau yang sering disebut design sprint terbagi menjadi 5 (lima) tahapan. Kelima tahapan ini terlihat seperti Gambar 2 berikut ini.

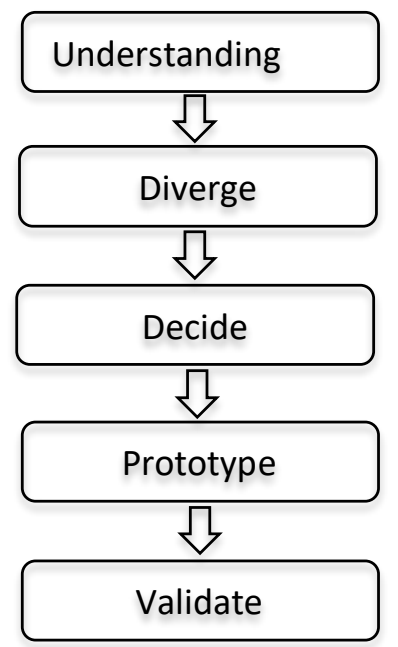

Gambar 2. Metode Design Sprint
Pada tahapan understanding (memahami) ini, tujuan utamanya adalah memahami target dari masalah yang dihadapi petani, khususnya mitra. Untuk itu tim mahasiswa ditugaskan untuk memahami target masalah yang dihadapi oleh mitra dan beberapa petani. Agar mahasiswa lebih focus dalam proses penggalian data ini, tim mentor mengarahkan bagaimana mahasiswa tersebut harus menggali data ke lapangan. Tahapan understanding ini, dikerjakan mulai bulan Oktober 2017 sampai dengan bulan November 2017. Gambar 3 berikut ini menunjukkan salah satu proses memahami (understanding) memahami permasalahan yang dihadapi oleh mitra.

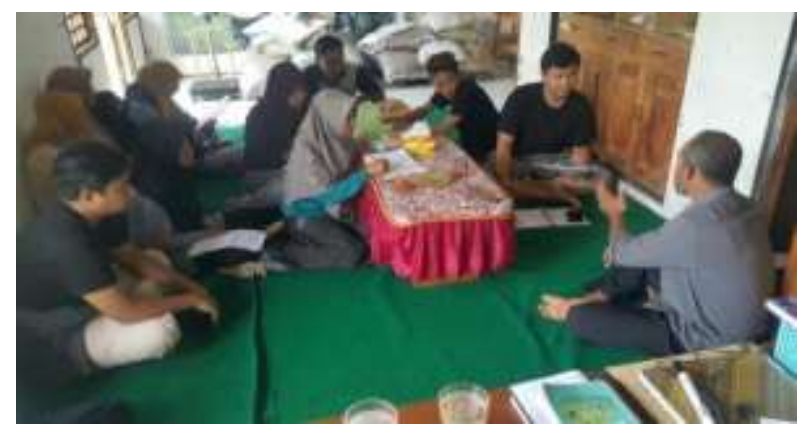

Gambar 3. Tahapan Understanding

Tahap selanjutnya adalah diverge (kembangkan). Tujuan dari tahap ini adalah merumuskan solusi sebanyak-banyaknya dari permasalahan yang dihadapi oleh mitra terutama petani. Perlu dicatat, bahwa perumusan solusi ini dimulai dari penggalian ide, dimana ide-ide solusinya bisa dimbil dari idenya mitra, ide dari tim mahasiswa maupun ide dari tim mentor. Tahapan ini dikerjakan pada bulan Desember 2017. Gambar 4 berikut ini menunjukkan proses diverge. 


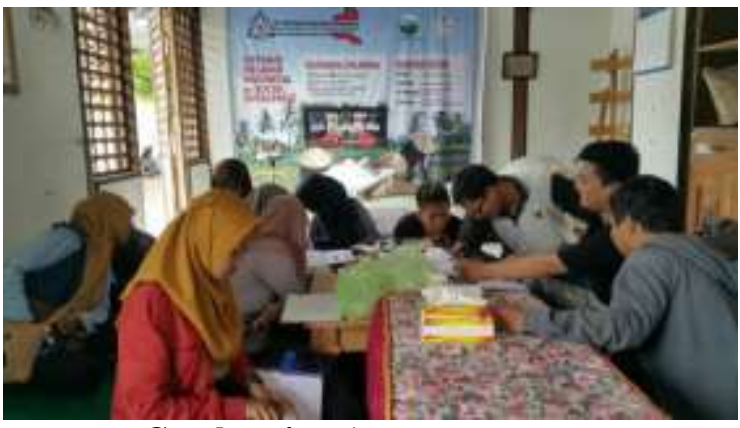

Gambar 4. Tahapan Diverge

Selesai tahapan diverge (pembagian), maka langkah selanjutnya adalah tahap decide (memutuskan). Tujuan utama tahap ini adalah memutuskan mana masalah utama yang dihadapi petani dan mana solusi utama yang dirumuskan oleh tim. Untuk selanjutnya, hasil keputusan permasalahan dan solusi utama inilah yang akan dieksekusi menjadi prototype produk startup. Gambar 5 ini menunjukkan proses memutuskan masalah dan solusi utamanya.

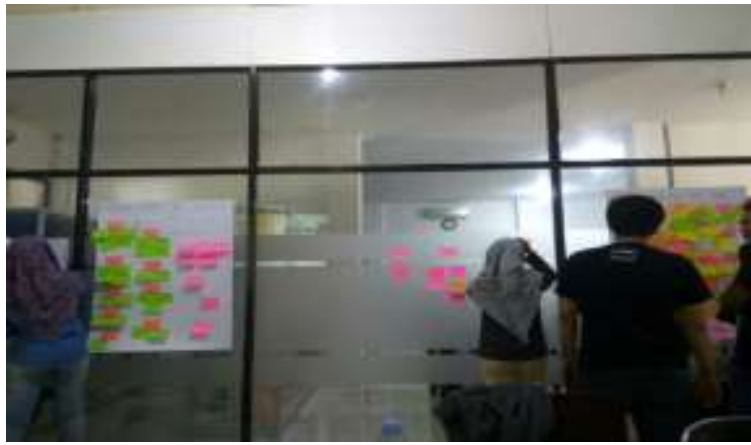

Gambar 5. Tahapan Decide

Tahap yang keempat adalah membangun prototype produk. Adapun prototype produk pengabdian kepada masyarakat ini adalah berupa perangkat lunak (software) yang berfungsi sebagai sarana untuk promosi dan penjualan beras organik. Tahapan pembuatan prototype ini, dikerjakan mulai bulan Februari 2018 sampai dengan bulan Maret 2018. Gambar 6 ini menunjukkan tampilan website online marketing (ecommerce) yang bisa diakses pada alamat URL https://organiku.id.

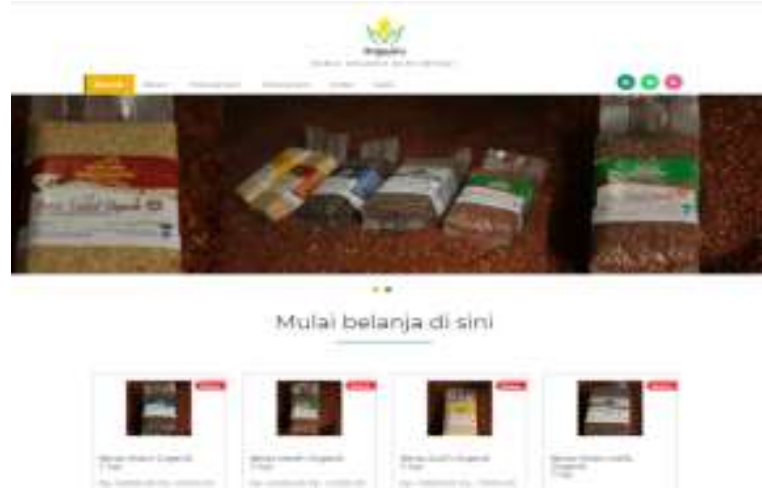

Gambar 6. Tampilan Website Organiku.id

Tahap yang kelima adalah tahap uji coba prototype (validate). Pada tahapan ini, tim mahasiswa melakukan uji prototype dengan cara mempromosikan keberadaan website penjualan beras organik sekaligus memnjual beras organik ke masyarakat di Banyuwangi. Gambar 7 berikut ini menunjukkan proses validasi prototype sekaligus penjulana beras organik ke masyarakat Banyuwangi. Tahap uji prototype atau validasi ini, mulai dikerjakan sejak bulan April 2018 sampai dengan Januari 2019.

Pada tahap ini, tim mahasiswa terjun langsung ke lapangan guna mempromosikan beras organik sekaligus memperkenalkan website organiku.id. Adapun lokasi-lokasi yang dipilih oleh tim mahasiswa adalah pusatpusat keramaian seperti taman Sritanjung, taman Blambangan, pantai Boom dan lokasilokasi strategis lainnya. 


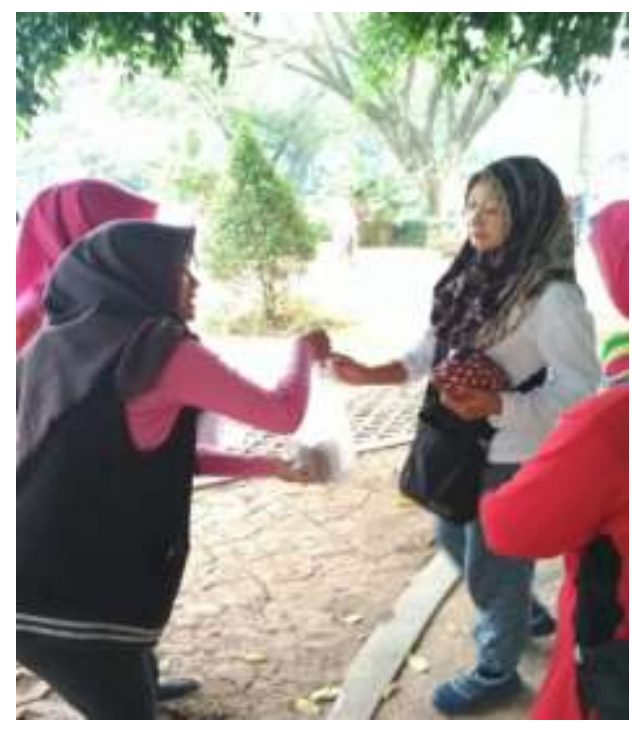

Gambar 7. Tahapan Validasi Prototype

\section{C.HASIL DAN PEMBAHASAN}

Dari serangkaian kegiatan ini, didapatkan hasil bahwa penjualan beras organik di Kabupaten Banyuwangi berhasil dilaksanakan. Adapun hasil penjualan beras organik selama bulan April 2018 sampai dengan Januari 2019, terlihat pada Tabel 3 berikut ini.

Tabel 3. Jumlah Penjualan Beras Organik

\begin{tabular}{cc}
\hline Bulan & Penjualan $(\mathrm{Kg})$ \\
\hline April, 2018 & 30 \\
\hline Mei, 2018 & 45 \\
\hline Juni, 2018 & 10 \\
\hline Juli, 2018 & 27 \\
\hline Agustus, 2018 & 27 \\
\hline September, 2018 & 36 \\
\hline Oktober, 2018 & 16 \\
\hline November, 2018 & 32 \\
\hline Desember, 2018 & 11 \\
\hline Januari, 2019 & 23 \\
\hline TOTAL & 257
\end{tabular}

Adapun grafik penjualan beras organik sejak bulan April 2018 sampai dengan bulan Januari 2019 seperti tertera pada Gambar 8 berikut ini.

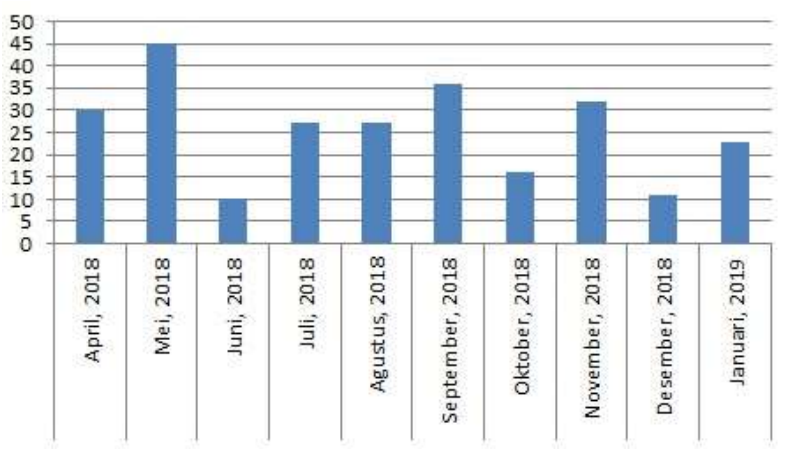

Gambar 8. Grafik Penjualan

Agar penjualan beras organik ini bisa dipertanggung jawabkan secara hukum, maka kegiatan pembangunan perusahaan rintisan atau startup ini perlu dilegalkan menurut undang-undang yang berlaku. Untuk itu, perusahaan yang dibangun dari proses pengembangan startup ini, saat ini sudah berbentuk perusahaan berbadan hukum dengan bentuk "PERSEROAN KOMANDITER" yaitu CV. PIPO ORGANIKU, akta notaris nomor 36 tertanggal 24 September 2018, yang dibuat oleh Notaris Yoga Pandawa, SH. M.Kn.

\section{Pembahasan}

Guna mendukung penjualan beras organik secara online, digunakan perangkat lunak berupa website yang bisa diakses pada halaman URL https://organiku.id.

Website organiku.id ini sementara ini masih menyediakan fasilitas untuk menampilkan daftar produk beras organik dan beberapa foto gallery. Untuk layanan pembayaran online yang memanfaatkan transfer bank, sampai saat ini belum disediakan. Hal ini disebabkan transaksi jualbeli beras organik mayoritas masih memanfaatkan fasilitas chatting.

Website organiku.id sampai saat ini masih belum bisa melayani transaksi jual-beli secara mandiri, seperti selayaknya aplikasi e- 
commerce yang ada seperti bukalapak, tokopedia dan lain sebagainya. Layanan website organiku.id masih tergantung layanan social media seperti instagram, facebook dan whatsapp terutama untuk proses promosi dan transaksi penjualan.

Dari grafik penjualan, dapat dilihat bahwa transaksi penjualan masih belum stabil. Seperti yang terlihat pada bulan Juni tahun 2018, Oktober 2018 dan Desember 2018, transaksi penjualan mengalami penurunan. Setelah dievaluasi, penurunan penjualan beras ini diakibatkan karena menurunnya intesitas promosi di social media, sehingga berdampak pada menurunnya transaksi penjualan. Dari sisi bisa disimpulkan bahwa sampai saat ini, pengaruh social media masih sangat dominan terhadap tingkat penjualan beras organik. Dan dari kenyataan ini bisa diambil benag merahnya bahwa konsumen sapai saat ini masih sangat membutuhkan edukasi mengenai keberadaan dan manfaat dari beras organik.

Kegiatan bisnis yang didukung dengan legalitas badan hukum yang jelas, ternyata mampu memaksimalkan tingkat kepercayaan konsumen. Ketika dalam kegiatan promosi di social media disampaikan bahwa perusahaan rintisan atau startup ini mempunyai badan hokum, maka beberapa konsumen percaya dan akhirnya melakukan transaksi pembelian.

\section{PENUTUP}

\section{Simpulan}

Dari serangkaian kegiatan yang dikemas ke dalam inovasi pengembangan startup ini, terbukti bisa meningkatkan jumlah transaksi penjualan beras organik. Terbukti dari bulan April 2018 sampai dengan januari 2019, tercatat sudah ada transaksi penjualan beras organik sebanyak 257 kilogram $(\mathrm{Kg})$.

Proses transaksi penjualan beras organik secara online melalui website https://organiku.id masih perlu didukung dengan promosi yang gencar melalui sosial media seperti instagram, facebook dan whatsapp.

Kegiatan usaha perusahaan rintisan (startup) penjualan beras organik ini sudah mempunyai legalitas secara hukum, yang ditandai dengan keberadaan perusahaan perseroan komanditer (CV) yaitu CV. Pipo Organiku dengan akta notaris nomor 36 tanggal 24 September 2018, yang dibuat oleh notaris Yoga Pandawa, S.H. M.Kn.

Metode google design sprint, terbukti sangat efektif untuk pengembangan perusahaan rintisan atau startup. Terbukti dari kegiatan yang dimulai pada bulan Oktober 2017, sudah berhasil memetakan arah bisnis perusahaan, dan pada bulan September 2018 sudah berhasil melahirkan 2 (dua) buah perusahaan rintisan baru.

\section{Saran}

Menurut hasil rapat koordinasi nasional (rakornas) yang diselenggarakan Kemenristekdikti, dihasilkan keputusan bahwa perguruan tinggi perlu menyelenggarakan inovasi kepada masyarakat dan industri melalui model pembelajaran startup dan teaching factory. Khusus untuk startup atau perusahaan rintisan, perlu ditelaah betul-betul bagaimana memetakan permasalahan dan solusi yang optimal. Untuk memetakan permasalahan dan solusi yang optimal ini, penerapan google design sprint sangat membantu.

Penjualan beras organik bisa diklasifikasikan sebagai hilir dari serangkaian proses pertanian. Permasalahan petani sangatlah kompleks, mulai dari ketersediaan modal, pemahaman tentang teknologi bertani yang baik dan sebagainya. Untuk itu, dalam kegiatan inovasi bagi masyarakat khususnya petani, perlu dibangun juga perusahaanperusahaan rintisan yang bisa menghadirkan solusi permodalan dan pendampingan dan pembelajaran bagi petani. 


\section{Ucapan Terima Kasih}

Melalui tulisan ini disampaikan terikasih kepada LP3M STIKOM PGRI Banyuwangi yang bertanggung jawab kepada kegiatan pengabdian kepada masyarakat dan mitra PT. Sirtanio Indonesia, Banyuwangi, Jawa Timur.

\section{E. DAFTAR PUSTAKA}

U. Nations. 2009. The state of food and agriculture.

Banyuwangikab.go.id. 2016. Beras Organik Banyuwangi Tembus Pasar Amerika Serikat dan Belanda, diakses: https://www.banyuwangikab.go.id/beritadaerah/beras-organik-banyuwangitembus-pasar-amerika-serikat-danbelanda.html.

Knapp J. 2017. Sprint Pecahkan MasalahMasalah Besar dan Uji Ide-Ide Baru Hanya dalam 5 Hari, Bentang Pustaka.

Peraturan Menteri Riset. Teknologi dan Pendidikan Tinggi. 2015. Rencana Strategis Kementerian Riset. Teknologi dan Pendidikan Tinggi, Nomor 13 tahun 2015. 